\title{
ANOMALIES OF THE AORTA AND PULMONARY ARTERIES COMPLICATING VENTRICULAR SEPTAL DEFECT
}

BY

\author{
J. MORGAN, R. PITMAN, J. F. GOODWIN, R. E. STEINER, AND A. HOLLMAN
}

From the Departments of Medicine and Radiodiagnosis, Postgraduate Medical School and Hammersmith Hospital

Received August 15, 1961

Ventricular septal defect is not always a simple lesion, but may be associated with other congenital cardiac disorders. The object of this paper is to present anomalies of the great vessels that have been found on angiocardiography or at operation in a series of patients with a ventricular septal defect investigated and treated at Hammersmith Hospital.

During the last three years selective angiocardiography has been performed on 165 patients diagnosed as having ventricular septal defect. In 24 of them associated anomalies of the aorta and pulmonary arteries have been found. These patients will be presented in three groups according to the type of anomalies found; Group 1, corrected transposition of the great vessels, Group 2, double outlet right ventricle, Group 3, anomalies of the pulmonary arteries.

\section{Group 1. Corrected Transposition of the Great Vessels}

In this anomaly there is anatomical transposition. Viewed from above the aorta is anterior and to the left and the pulmonary trunk posterior and to the right. This is corrected functionally by bulboventricular inversion. Corrected transposition is usually associated with other defects, but the circulation is normal, for venous blood enters the pulmonary circulation and arterial blood the systemic circulation. The systemic ventricle from which the aorta arises has the anatomical features of a right ventricle, and the venous ventricle, from which the pulmonary artery arises, has the anatomical characteristics of a left ventricle.

The anatomy of this anomaly has been described by others: Rokitansky (1875), Spitzer (1923), and Cardell (1956). The clinical features have been quoted more recently by Anderson et al. (1957), Kjellberg et al. (1959), Schiebler et al. (1961), and Beck et al. (1961).

In our series of 165 patients investigated by angiocardiography there were 13 with corrected transposition (Table I); five were female and eight male, and their ages ranged from three to twenty years. All except one had a ventricular septal defect, which was associated with pulmonary stenosis in seven and with mitral regurgitation in three. Although the systemic atrioventricular valve is anatomically tricuspid we have retained the term mitral regurgitation for ease of clinical description. Two patients had dextrocardia and one, the only patient without a ventricular septal defect, had pulmonary subvalvular stenosis.

We have found no diagnostic features on physical examination. One patient with ventricular septal defect and pulmonary stenosis demonstrated a sign described by Nadas (1961). In this patient aortic closure was heard best in the pulmonary area, not at the lower left sternal edge as is more usual in the tetralogy of Fallot. Although no other helpful diagnostic signs were found we consider that the association of mitral regurgitation with a ventricular septal defect should always arouse the suspicion of corrected transposition. 
TABLE I

CORRECTED TRANSPOSITION

\begin{tabular}{|c|c|c|c|c|c|c|c|}
\hline \multirow{2}{*}{ Patient } & \multirow{2}{*}{$\begin{array}{c}\text { Age in } \\
\text { years and sex }\end{array}$} & \multirow{2}{*}{$\begin{array}{l}\text { Associated } \\
\text { defects }\end{array}$} & \multirow{2}{*}{$\begin{array}{l}\text { Ratio of } \\
\text { pulmonary to } \\
\text { systemic } \\
\text { blood flow }\end{array}$} & \multirow{2}{*}{$\begin{array}{l}\text { Arterial } \\
\text { saturation } \\
\text { per cent }\end{array}$} & \multicolumn{2}{|c|}{ Hæmodynamics } & \multirow{2}{*}{ Mode of diagnosis } \\
\hline & & & & & $\begin{array}{l}\text { R.V.P. } \\
\text { mm. Hg }\end{array}$ & $\begin{array}{l}\text { P.A.P. } \\
\text { mm. Hg }\end{array}$ & \\
\hline 1. S. W. & $\begin{array}{c}15 \\
\text { female }\end{array}$ & $\begin{array}{l}\text { P.S. V.S.D. } \\
\text { dextrocardia }\end{array}$ & - & 78 & $105 / 10$ & 18 & $\begin{array}{l}\text { Operation } \\
\text { Necropsy }\end{array}$ \\
\hline 2. M.R. & $\begin{array}{c}7 \\
\text { male }\end{array}$ & $\begin{array}{l}\text { "M.I." } \\
\text { V.S.D. }\end{array}$ & $2 \cdot 2: 1$ & 92 & $110 / 5$ & $110 / 50$ & Operation \\
\hline 3. B.A. & $\begin{array}{c}20 \\
\text { male }\end{array}$ & P.S. V.S.D. & $2 \cdot 4: 1$ & 89 & $130 / 0$ & - & Angiocardiography \\
\hline 4. T.F. & $\begin{array}{c}10 \\
\text { male }\end{array}$ & P.S. & - & 97 & $85 / 0$ & $12 / 2$ & $\begin{array}{l}\text { Angiocardiography } \\
\text { Operation }\end{array}$ \\
\hline 5. P.G. & $\begin{array}{c}6 \\
\text { male }\end{array}$ & P.S. V.S.D. & $2 \cdot 1: 1$ & 95 & $100 / 0$ & $15 / 3$ & $\begin{array}{l}\text { Angiocardiography } \\
\text { Operation }\end{array}$ \\
\hline 6. V.P. & $\begin{array}{c}8 \\
\text { female }\end{array}$ & P.S. V.S.D. & $2 \cdot 8: 1$ & 91 & $100 / 0$ & $30 / 10$ & $\begin{array}{l}\text { Angiocardiography } \\
\text { Necropsy }\end{array}$ \\
\hline 7. D.B. & $\begin{array}{c}15 \\
\text { male }\end{array}$ & $\begin{array}{l}\text { P.S. V.S.D. } \\
\text { dextrocardia }\end{array}$ & $1 \cdot 2: 1$ & 97 & $105 / 0$ & $10 / 3$ & Angiocardiography \\
\hline 8. R.B. & $\begin{array}{c}14 \\
\text { male }\end{array}$ & P.S. V.S.D. & 1.9:1 & 88 & $154 / 0$ & $27 / 16$ & Angiocardiography \\
\hline 9. N.M. & $\begin{array}{c}3 \\
\text { male }\end{array}$ & $\begin{array}{l}\text { "M.I." } \\
\text { V.S.D. }\end{array}$ & $2: 1$ & 97 & $75 / 20$ & $70 / 0$ & Necropsy \\
\hline 10. W.B. & $\begin{array}{c}5 \\
\text { female }\end{array}$ & V.S.D. & $1 \cdot 9: 1$ & 92 & $75 / 5$ & $72 / 36$ & Angiocardiography \\
\hline 11. C.McK & $\begin{array}{c}4 \\
\text { female }\end{array}$ & V.S.D. & $4: 1$ & 97 & $100 / 5$ & - & Angiocardiography \\
\hline 12. A.B. & $\begin{array}{c}5 \\
\text { male }\end{array}$ & "M.S.D.; & $2 \cdot 3: 1$ & 89 & $90 / 0$ & $90 / 60$ & $\begin{array}{l}\text { Cardiac } \\
\text { catheterization }\end{array}$ \\
\hline 13. J.T. & $\begin{array}{c}10 \\
\text { female }\end{array}$ & V.S.D. P.S. & $1 \cdot 5-2 \cdot 5: 1$ & 88 & $80 / 7$ & - & Angiocardiography \\
\hline
\end{tabular}

P.S. $=$ Pulmonary stenosis

R.V.P. $=$ Right ventricular pressure

V.S.D. $=$ Ventricular septal defect P.A.P.=Pulmonary artery pressure

"M.I."="Mitral" incompetence

Electrocardiography has been of great assistance in diagnosis due to the presence of a characteristic pattern in præcordial leads (Fig. 1). All patients have shown a $Q R$ pattern in right præcordial leads, with an RS pattern in left præcordial leads, the normal left præcordial $\mathrm{Q}$ wave being absent. The changes may, of course, resemble right ventricular hypertrophy. In most of our patients, however, the $\mathrm{Q}$ wave in right precordial leads has been large in proportion to the $\mathrm{R}$ wave rather than the reverse, as is usually the case in right ventricular hypertrophy. Complete heart block was established in two patients and paroxysmal in a third. Thus, the diagnosis was commonly suggested by the electrocardiographic findings and by the presence of established or episodic heart block. Figure 2 demonstrates the $\mathrm{QR}$ patterns found in right præcordial leads in 12 of our patients.

Radiology. The diagnosis may be suggested by the plain radiograph of the chest (Fig. 3). The left upper cardiac border is formed by the aorta, and is therefore prolonged and convex. The 


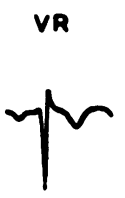<smiles>CCCCCCC(C)C</smiles>

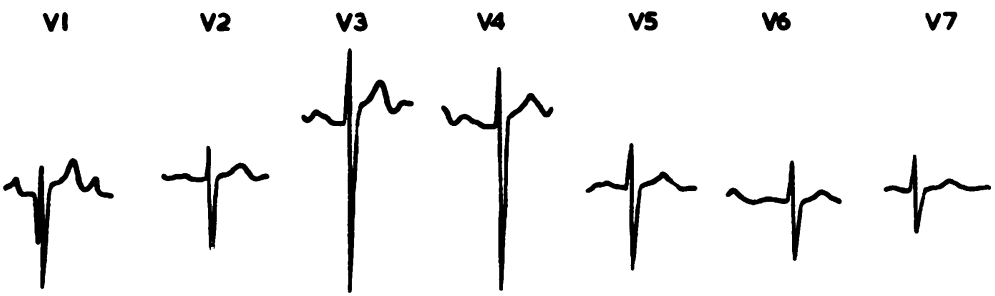

II

VF

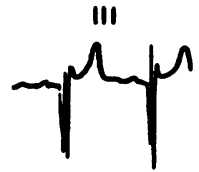

FIG. 1.-Corrected transposition. Cardiogram of patient No. 2 in whom this anomaly was associated with ventricular septal defect and "mitral" regurgitation. A typical QR complex is shown in lead V1.

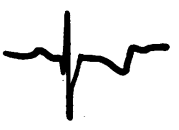

I. V2
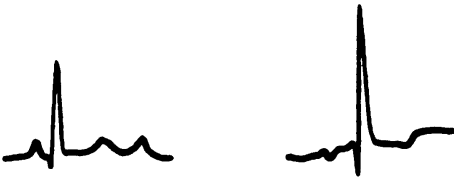

6. VI

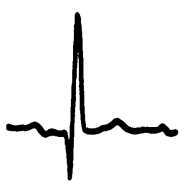<smiles>CCC[C@@H]1C[C@H](C)[C@H](CC)C1</smiles>
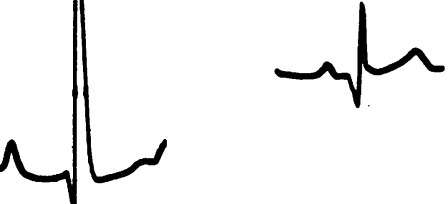

3. VAR

4. VI
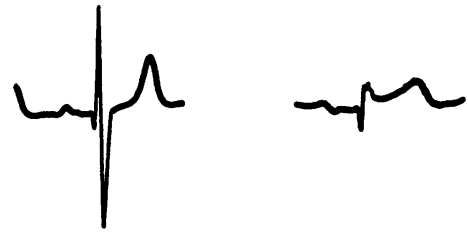

7. V2

8. V4R<smiles>CCCCCCCCCCCCC</smiles>

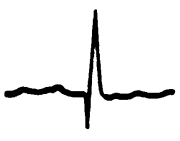

9. VAR

10. V4R

II. VAR

12. V6R

FIG. 2.-Corrected transposition. Cardiographic complexes found in right præcordial leads. Figures refer to patients. Patients Nos. 1 and 7 had dextrocardia, therefore lead V2 was used to correspond to normal lead V1. Leads V4R and V6R were used in some patients, as corresponding leads V1 or V4R had RS complexes. 

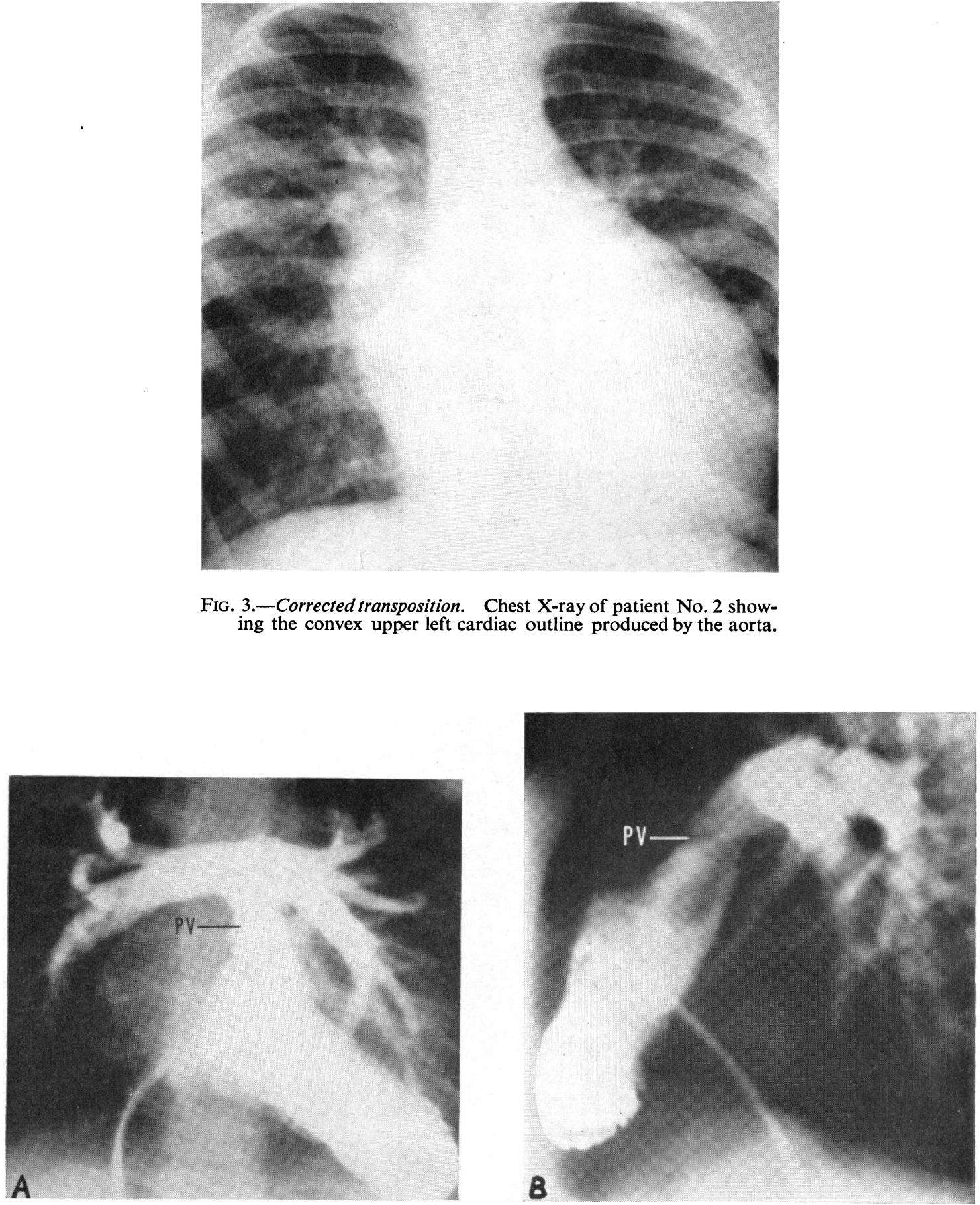

FIG. 4.-Corrected transposition. Right ventricular angiocardiogram of patient No. 5. Pulmonary valve stenosis (PV) is also present. The ventricular septal defect is not shown in these films. (A) Antero-posterior projection. (B) Lateral projection. 3.- Corrected transposition. Chest X-ray of patient No. 2 show-
ing the convex upper left cardiac outline produced by the aorta. 
outline of the pulmonary artery, which occupies a midline position, is not seen, even in the presence of poststenotic dilatation. Thus, the presence of obviously overfilled lungs with a convex left border to the heart and absence of the characteristic shadows of the main pulmonary arteries should suggest the diagnosis. The pulmonary trunk may indent the left side of the barium filled œsophagus.

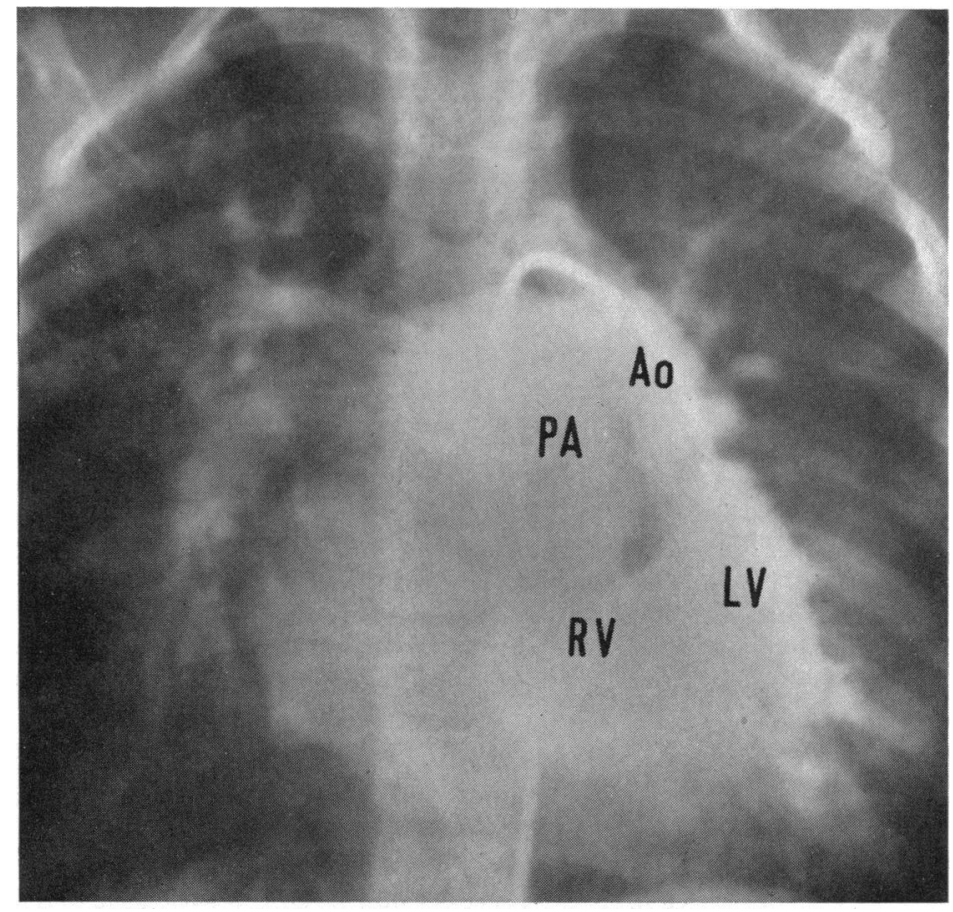

FIG. 5.-Corrected transposition. Retrograde left ventricular angiocardiogram of patient No. 10; antero-posterior projection. The typical position of the aorta is shown by the catheter. The pulmonary trunk lies in a midline position and fills from the ventricular septal defect. Ao $=$ aorta. $\quad L V=$ left ventricle. $\quad P A=$ pulmonary artery. $\quad R V=$ right ventricle.

Cardiac Catheterization. This may suggest the diagnosis, and occasionally confirm it. The pulmonary trunk, however, is difficult to enter with the catheter because of its unusual position. The aorta may be entered from the right side, through the ventricular septal defect, demonstrating its position along the left cardiac border. Hæmodynamic features and intra-cardiac shunts are listed in Table I, the pulmonary blood flow being expressed as a ratio of the systemic flow. Arterial oxygen saturations demonstrated a right-to-left shunt in four patients, all of whom had severe pulmonary stenosis.

We consider that right ventricular angiocardiography is the most satisfactory method of making the diagnosis, which rests on the features of the venous ventricle and its out-flow tract (Fig. 4). The pulmonary trunk lies in the midline to the right of the aorta with an unusual $\mathrm{T}$ shaped arrangement of the main trunk and its main branches. The lateral projection demonstrates the characteristic posterior position of the pulmonary trunk behind the aorta. The venous ventricle has the features of a normal left ventricle. It is triangular in shape, there is only a short out-flow tract, the crista 


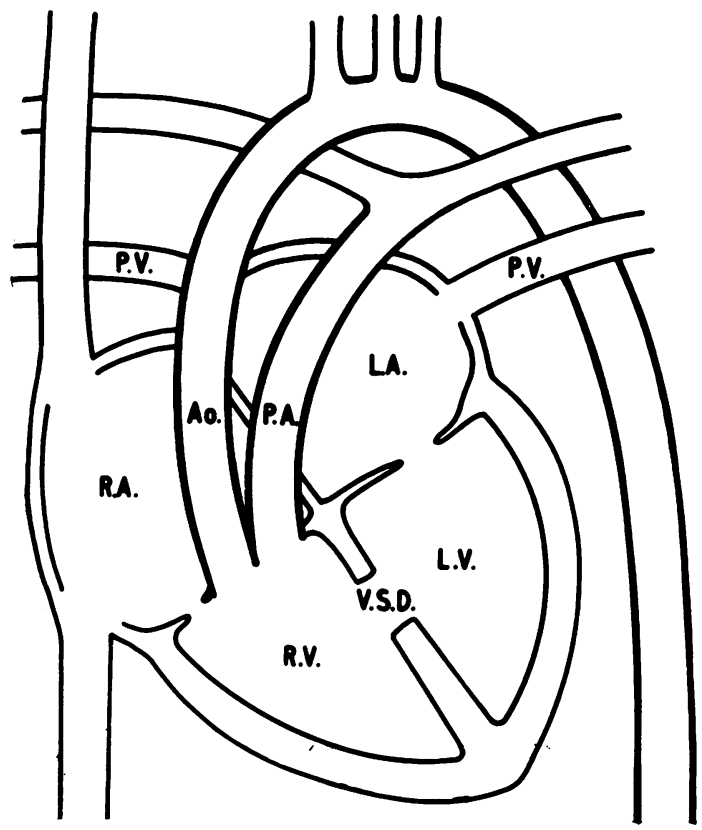

FIG. 6.-Double outlet right ventricle. Diagram illustrating the position of the great vessels. Ao=aorta. $L A=$ left atrium. $L V=$ left ventricle. $\mathbf{P V}=$ pulmonary vein. $\mathbf{P A}=$ pulmonary artery. $\mathbf{R A}=$ right atrium. $\quad \mathbf{R V}=$ right ventricle. V.S.D. = ventricular septal defect. supraventricularis is absent, and the outline is smooth, due to the lack of trabeculation. The arterial ventricle has the features of a right ventricle, being divided into separate in-flow and out-flow portions, having a prominent crista supraventricularis and irregular outline. The aorta lies to the left of the pulmonary trunk, and in the lateral projection is slightly anterior and tends to overlie the pulmonary trunk (Fig. 5). We have not found the aorta in the extreme anterior position characteristic of complete uncorrected transposition.

\section{Group 2. Double Outlet Right Ventricle}

This term is used to denote an anomaly in which both pulmonary trunk and aorta rise from the right ventricle. A ventricular septal defect is always present, for this is the only outlet for blood from the left ventricle (Fig. 6). There were seven patients in this group, and these have been divided into two sub-groups, depending on the presence or absence of cyanosis. Those without cyanosis, with normal arterial oxygen saturation, were found to have a low pulmonary vascular resistance and no

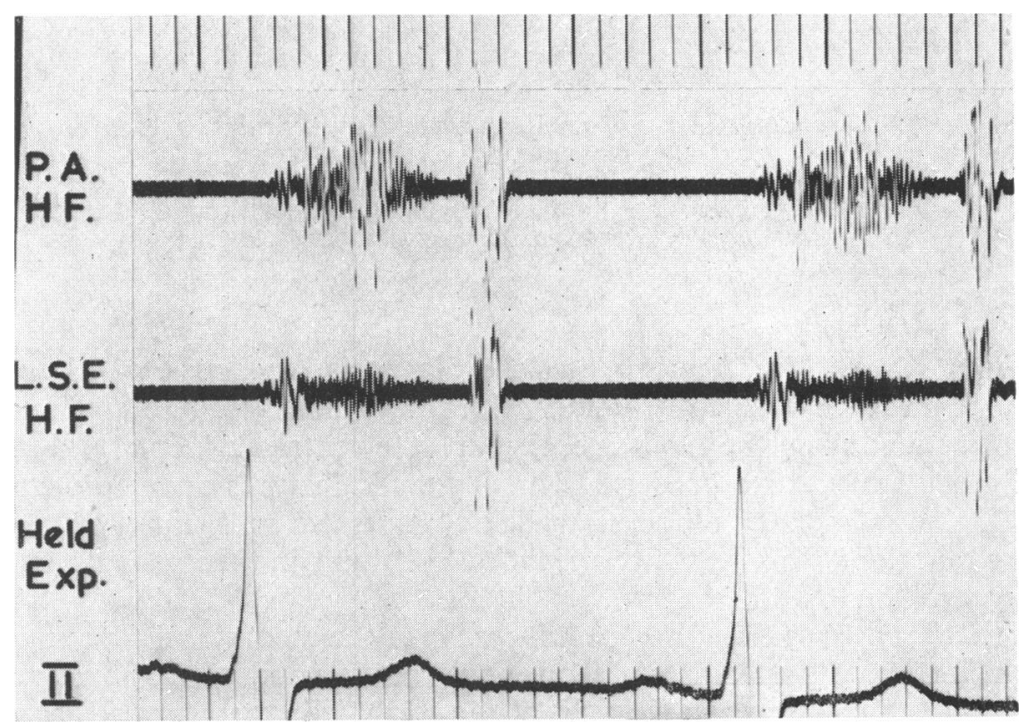

FIG. 7.-Double outlet right ventricle. Phonocardiogram of patient No. 3 demonstrating ejection systolic murmur produced by a narrow aortic outlet. $\mathbf{P A}=$ pulmonary area. $\mathrm{LSE}=$ left sternal edge. $\mathrm{HF}=$ high frequency. 
obstruction to the outflow of the right ventricle. The patients in the second sub-group were cyanosed, with a diminished arterial oxygen saturation, and they could be divided into two types as suggested by Witham (1957), depending on the site of obstruction to blood flow to the lungs. Thus, those with an extremely high pulmonary vascular resistance and a right-to-left shunt were classified as resembling the Eisenmenger complex and those with pulmonary stenosis resembled the tetralogy of Fallot.

The acyanotic patients presented with clinical signs of ventricular septal defect with a large left-toright shunt. We found the diagnosis of double outlet right ventricle extremely difficult to make clinically. However, the condition was suggested when patients were found to have a harsh ejection murmur in the aortic area conducted laterally, suggesting aortic stenosis (Fig. 7). A loud murmur was present in the deeply cyanotic patients who would otherwise have been expected to have short insignificant murmurs if they had been typical examples of the Eisenmenger complex or of the severe tetralogy of Fallot. Table II lists the patients and their details.

TABLE II

Double Outlet Right Ventricle

\begin{tabular}{|c|c|c|c|c|c|c|c|c|}
\hline \multirow{2}{*}{ Group } & \multirow{2}{*}{$\begin{array}{l}\text { Patient } \\
\text { and } \\
\text { sex }\end{array}$} & \multirow{2}{*}{$\begin{array}{l}\text { Age } \\
\text { years }\end{array}$} & \multirow{2}{*}{$\begin{array}{l}\text { Associated } \\
\text { defects }\end{array}$} & \multirow{2}{*}{$\begin{array}{l}\text { Pulmonary: } \\
\text { systemic } \\
\text { blood flow }\end{array}$} & \multirow{2}{*}{$\begin{array}{c}\text { Arterial } \\
\text { saturation } \\
\text { per cent }\end{array}$} & \multicolumn{2}{|c|}{ Hæmodynamics } & \multirow{2}{*}{ Mode of diagnosis } \\
\hline & & & & & & $\begin{array}{l}\text { R.V.P. } \\
\text { mm. Hg }\end{array}$ & $\begin{array}{l}\text { P.A.P. } \\
\text { mm. Hg }\end{array}$ & \\
\hline & $\begin{array}{l}\text { M.W. } \\
\text { male }\end{array}$ & 6 & $\begin{array}{l}\text { N.A.O. } \\
\text { V.S.D. }\end{array}$ & $2: 1$ & 98 & $94 / 0$ & $52 / 25$ & Operation \\
\hline \multirow{3}{*}{ 1. Acyanotic } & $\begin{array}{l}\text { S. } \\
\text { male }\end{array}$ & 1 & $\begin{array}{l}\text { N.A.O. } \\
\text { V.S.D. }\end{array}$ & $4: 1$ & 97 & $75 / 0$ & $45 / 5$ & Necropsy \\
\hline & $\begin{array}{l}\text { 3. } \\
\text { male }\end{array}$ & 16 & $\begin{array}{l}\text { N.A.O. } \\
\text { V.S.D. }\end{array}$ & $3: 1$ & 97 & $120 / 0$ & $120 / 70$ & Necropsy \\
\hline & $\begin{array}{l}\text { 4. } \\
\text { R.L. } \\
\text { male }\end{array}$ & 26 & V.S.D. & $2: 1$ & 96 & $120 / 0$ & $135 / 40$ & Angiocardiography \\
\hline \multirow{2}{*}{$\begin{array}{l}\text { 2. Cyanotic } \\
\text { (a) Fallot type }\end{array}$} & $\begin{array}{l}\text { 5. } \\
\text { B.H. } \\
\text { male }\end{array}$ & 20 & $\begin{array}{l}\text { P.S. } \\
\text { V.S.D. }\end{array}$ & $3: 1$ & 83 & $110 / 10$ & $20 / 8$ & Necropsy \\
\hline & $\begin{array}{l}\text { R.R. } \\
\text { male }\end{array}$ & 12 & $\begin{array}{l}\text { P.S. } \\
\text { V.S.D. }\end{array}$ & P.A. satn. $65^{\circ} \%$ & 63 & $150 / 0$ & $25 / 12$ & $\begin{array}{l}\text { Angiocardiography } \\
\text { Necropsy }\end{array}$ \\
\hline $\begin{array}{l}\text { (b) } \\
\text { Eisenmenger } \\
\text { type }\end{array}$ & $\begin{array}{l}\text { A.K. } \\
\text { male }\end{array}$ & 44 & V.S.D. & $1 \cdot 3: 1$ & 71 & $140 / 5$ & $140 / 50$ & Angiocardiography \\
\hline
\end{tabular}

N.A.O. $=$ Narrowed aortic outlet

P.A. satn. = oxygen saturation in pulmonary artery Other abbreviations as in Table I

Necropsy. The pathology of this condition has been described by Rokitansky (1875), Spitzer (1923), and Harris and Faber (1939). In three specimens in our series, the pulmonary trunk arose in the normal anterior position from the right ventricle. The aorta arose also from the right ventricle to the right of the pulmonary trunk immediately above the tricuspid valve and behind the crista supraventricularis. The interior of the right ventricle of patient No. 3 is shown in Fig. 8 . The aortic outlet was narrowed in three patients, and, although the aortic valve was normal, it tended to arise in a high position. The narrowing of the aortic outlet apparently produced the ejection murmur. There was no subvalvular stenosis. 
In the acyanotic patients the electrocardiogram showed biventricular hypertrophy (Fig. 9). In the cyanotic patients only varying degrees of right ventricular hypertrophy were seen.

The radiograph of the chest did not have any special features, the vascular markings suggesting either pulmonary stenosis or a left-to-right shunt or severe pulmonary hypertension.

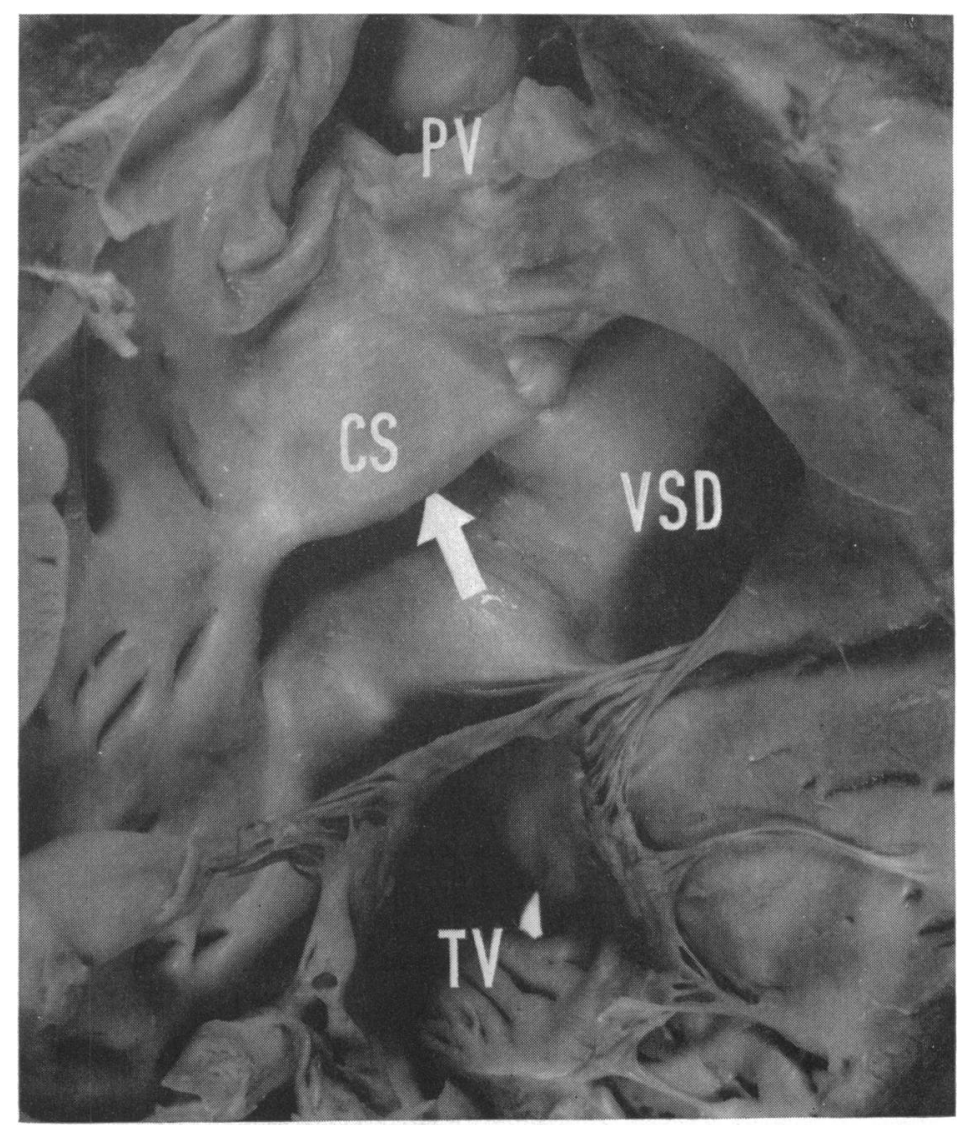

FIG. 8.-Double outlet right ventricle. Interior of the right ventricle of patient No. 3. The origin of the aorta is marked by the arrow. $\mathbf{C S}=$ crista supraventricularis. $\mathbf{P V}=$ pulmonary valve. $\mathrm{TV}=$ tricuspid valve. $\mathrm{VSD}=$ ventricular septal defect.

At cardiac catheterization a left-to-right shunt at ventricular level was demonstrated in all patients. This appears to be an essential feature of the anomaly. The aorta was entered from the right ventricle immediately above the tricuspid valve in one patient. The hæmodynamic data are shown in Table II.

The diagnosis can only be made by a selective angiocardiogram. When the injection was made into the right ventricle of the cyanotic patients (Fig. 10), both the aorta and pulmonary artery filled from the right ventricle: this occurred before there was any filling of the left ventricle. The antero-posterior films showed the pulmonary trunk arising in a normal position with the aorta lying to the right. In the lateral films, the aorta and pulmonary trunk were superimposed, with both vessels arising anteriorly. The aortic valve occupied an abnormally high position in some patients. 


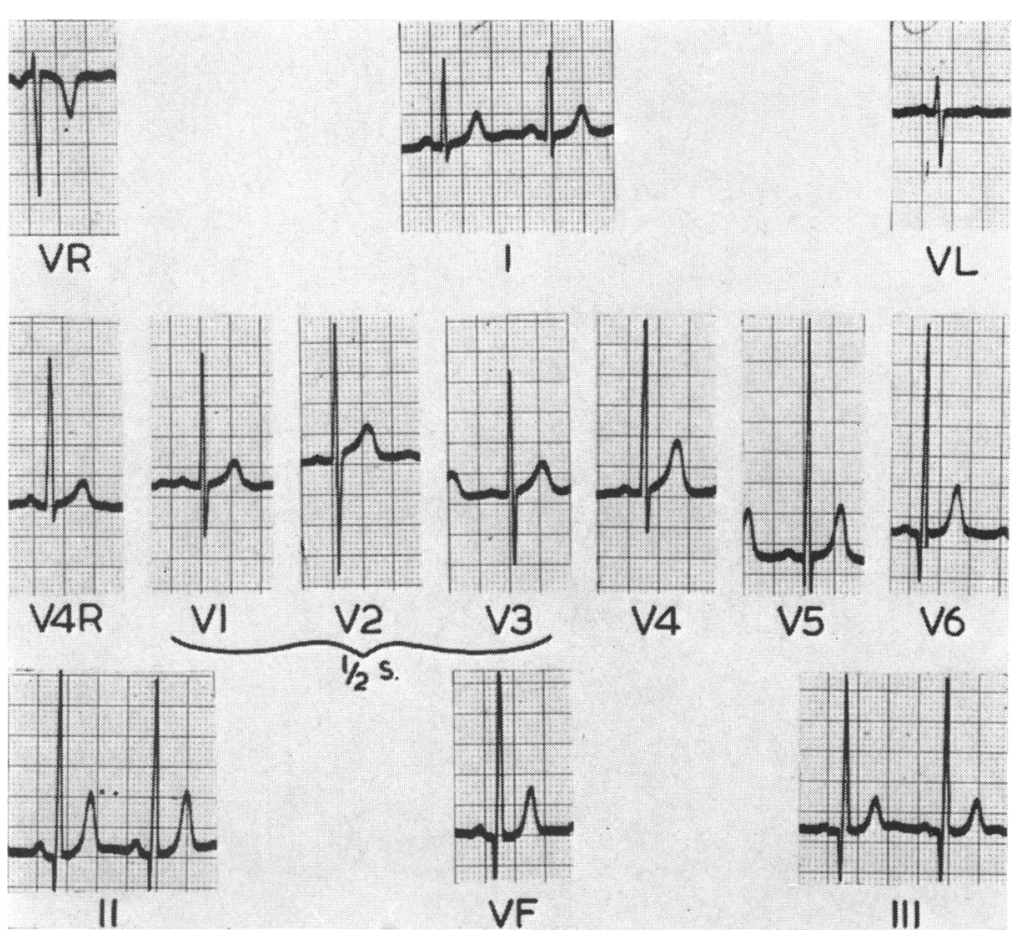

FIG. 9.-Double outlet right ventricle. Cardiogram of patient No. 1 showing right and left ventricular hypertrophy.

TABLE III

Anomalies of the Pulmonary Arteries

\begin{tabular}{l|c|c|c|c|c|c|l}
\hline Patient & $\begin{array}{c}\text { Age } \\
\text { years } \\
\text { and sex }\end{array}$ & $\begin{array}{c}\text { Pulmonary } \\
\text { artery } \\
\text { defect }\end{array}$ & $\begin{array}{c}\text { Associated } \\
\text { defects }\end{array}$ & $\begin{array}{c}\text { Ratio of pul- } \\
\text { monary to sys- } \\
\text { temic blood flow }\end{array}$ & $\begin{array}{c}\text { Hæ.V.P. } \\
\text { mm. Hg }\end{array}$ & $\begin{array}{c}\text { P.A.P. } \\
\text { mm. Hg }\end{array}$ & Mode of diagnosis \\
\hline 1. B.L. & $\begin{array}{c}10 \\
\text { Male }\end{array}$ & $\begin{array}{c}\text { Unilateral } \\
\text { stenosis }\end{array}$ & V.S.D. & $1 \cdot 8: 1$ & $60 / 0$ & $60 / 40$ & $\begin{array}{l}\text { Angiocardiography } \\
\text { Necropsy }\end{array}$ \\
\hline 2. G.B. & $\begin{array}{c}5 \\
\text { Female }\end{array}$ & $\begin{array}{c}\text { Unilateral } \\
\text { stenosis }\end{array}$ & $\begin{array}{c}\text { V.S.D. } \\
\text { A.S.D. }\end{array}$ & $2 \cdot 4: 1$ & $75 / 0$ & $75 / 25$ & $\begin{array}{l}\text { Angiocardiography } \\
\text { Operation }\end{array}$ \\
\hline 3. D.H. & $\begin{array}{c}12 \\
\text { Male }\end{array}$ & $\begin{array}{c}\text { Absent } \\
\text { L.P.A. }\end{array}$ & V.S.D. & $1 \cdot 4: 1$ & $90 / 5$ & $90 / 45$ & Angiocardiography \\
\hline 4. B.P. & $\begin{array}{c}7 \\
\text { Female }\end{array}$ & $\begin{array}{c}\text { R.P.A. } \\
\text { arising } \\
\text { from aorta }\end{array}$ & V.S.D. & $1 \cdot 3: 1$ & $135 / 0$ & $153 / 85$ & Angiocardiography \\
\hline
\end{tabular}

A.S.D. = Atrial septal defect L.P.A. = Left pulmonary artery
R.P.A. = Right pulmonary artery Other abbreviations as in Table I 

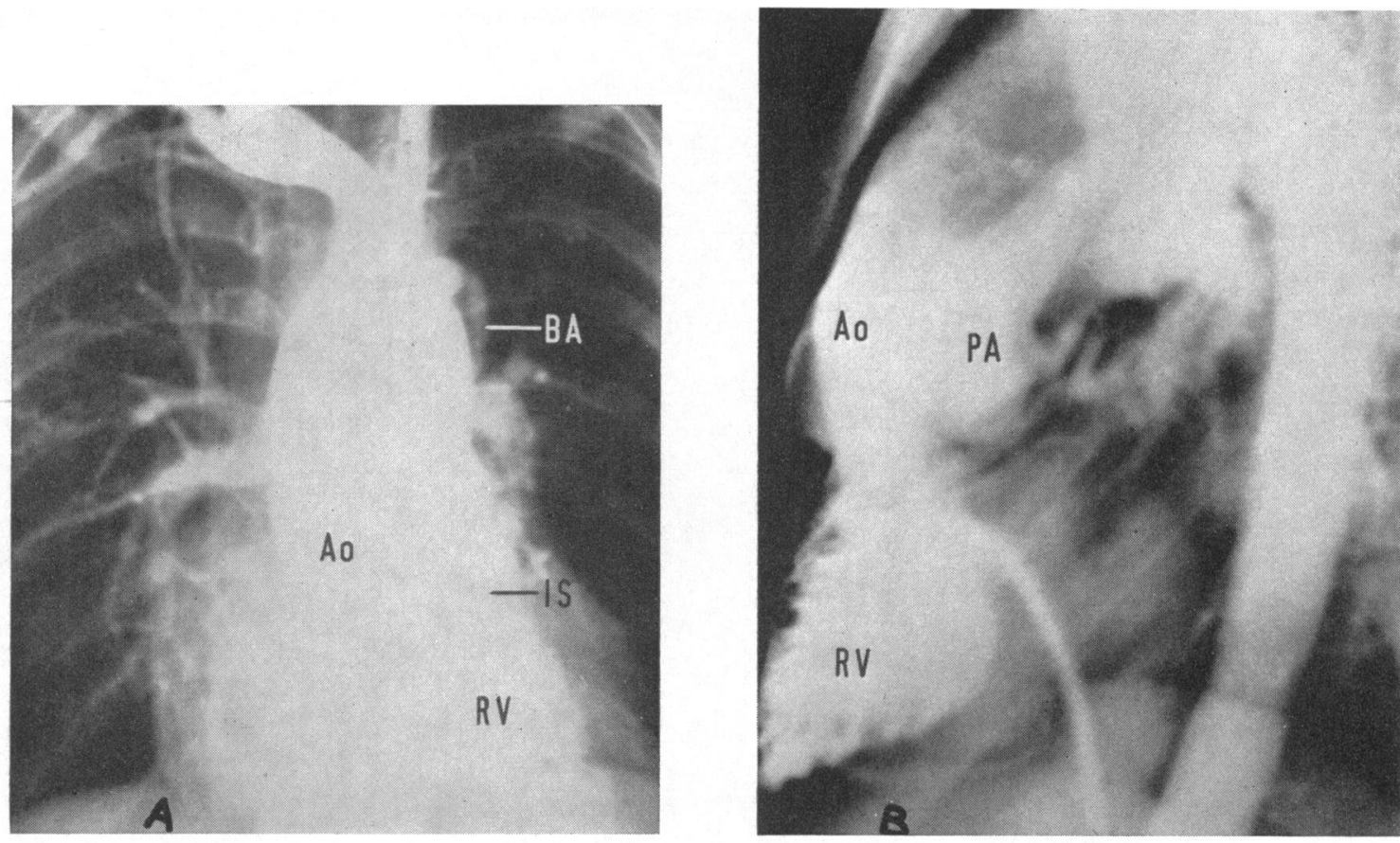

FIG. 10.-Double outlet right ventricle. Right ventricular angiocardiogram of patient No. 6 . Infundibular pulmonary stenosis (IS) and a previous Blalock anastomosis (BA) are also present. Ao=aorta. PA=pulmonary artery. $\mathrm{RV}=$ right ventricle. (A) Antero-posterior projection. (B) lateral projection.

Right ventricular angiocardiography is technically more difficult in the acyanotic group, because the contrast medium is diluted by a large left-to-right shunt. The anterior position of the aorta is an important diagnostic feature and is best shown by retrograde aortography (Fig. 11). A percutaneous left ventricular angiocardiogram was performed in one patient. This demonstrated that the only outlet from the left ventricle was a large ventricular septal defect. Through this defect the contrast medium outlined both the aorta and pulmonary artery.

\section{Group 3. Anomalies of the Pulmonary Arteries}

There were four patients in this group (Table III).

The first two had a ventricular septal defect associated with unilateral pulmonary stenosis, and one of these had an atrial septal defect in addition. Both patients had the usual signs of a ventricular septal defect, and in addition had a continuous murmur over the site of the branch stenosis. Such a murmur has previously been described (Arvidsson et al., 1955; Smith, 1958). It is thought to be due, in patients with severe pulmonary hypertension, to continuous flow across the stenosis both in systole and in diastole.

The electrocardiogram provided no diagnostic features. Radiography in both cases suggested unilateral stenosis by diminution in the vascular shadows distal to the stenosis and by post-stenotic dilatation of the branch involved. Cardiac catheterization in one patient revealed a gradient in the stenosed branch, and in both cases the stenosis was confirmed by angiography.

The third patient was a boy aged twelve years who presented with signs of a ventricular septal defect with severe pulmonary hypertension and mitral regurgitation. Radiography demonstrated 

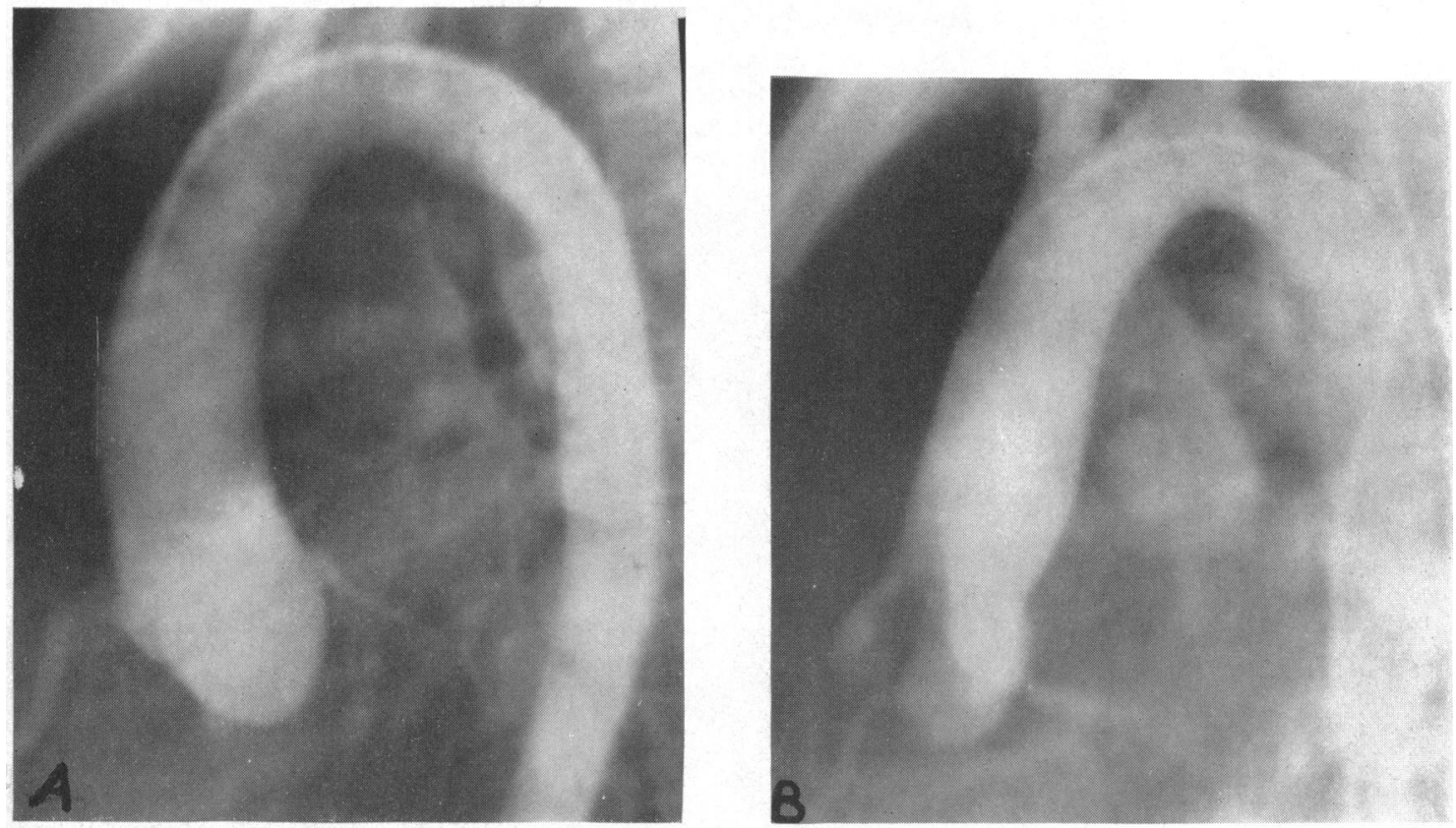

FIG. 11.-Double outlet right ventricle. (A) Aortogram of a patient with large ventricular septal defect and usual position of the great vessels showing normal aortic root. The aortic valve is directed downwards and backwards. (B) Aortogram of patient No. 4 showing the anterior position of the aorta in double outlet right ventricle. The aortic valve is directed downwards and forwards (lateral projection).

a reduction in the vascular markings of the left lung, suggesting that the vascular supply might be abnormal (Fig. 12). At cardiac catheterization, only one pulmonary artery could be entered and an angiogram showed that the left pulmonary artery was absent (Fig. 13). Left ventricular angiocardiography confirmed the presence of the ventricular septal defect, mitral regurgitation, and showed only a few bronchial anastomotic vessels supplying the left lung. Thus, the left pulmonary artery was completely absent.

The fourth patient was a girl aged seven years. She had the physical signs of ventricular septal defect with severe pulmonary hypertension. Radiography showed a large difference in the pulmonary vascular markings of the two lungs, the markings being more prominent on the right side. It was thought that the left pulmonary artery might be deficient, but at catheterization only the left pulmonary artery was entered. A selective right ventricular angiocardiogram (Fig. 14) showed that the right pulmonary artery did not arise from the right ventricle, but a selective left ventricular angiocardiogram (Fig. 15) demonstrated its origin from the aorta.

These anomalies of the pulmonary arteries were suspected from physical signs or from inspection of the plain chest X-ray, but their exact elucidation required selective angiocardiography.

\section{DisCUSSION}

The associated anomalies of the great vessels found in this series of patients with ventricular septal defect demonstrate the importance of selective angiocardiography. Without this investigation, the majority of these patients would have gone unrecognized, and surgical treatment might have been disastrous.

The diagnosis of thirteen patients with corrected transposition suggests that this is not an uncommon lesion. In this condition, while the physical signs were of little value, the electrocardiogram 


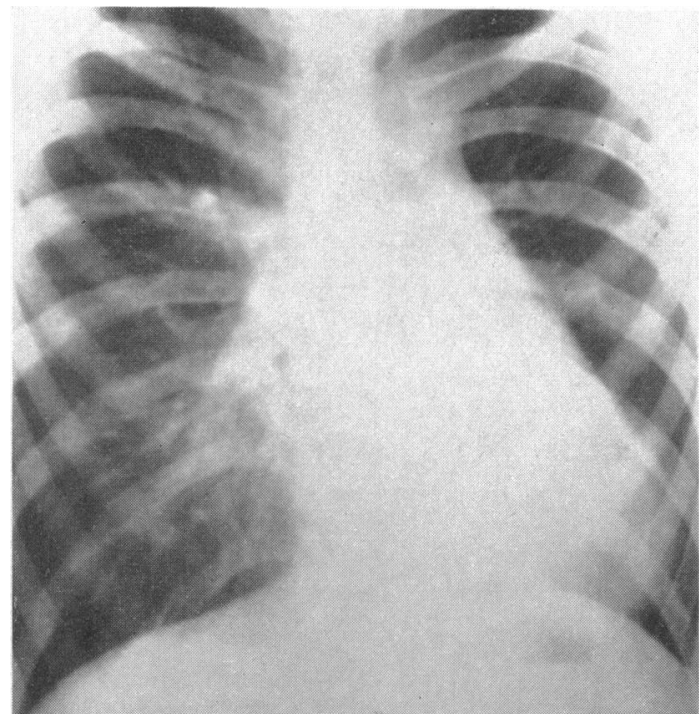

FIG. 12.-Anomalies of the pulmonary arteries. Anterior chest film of patient No. 3., whose left pulmonary artery was absent.

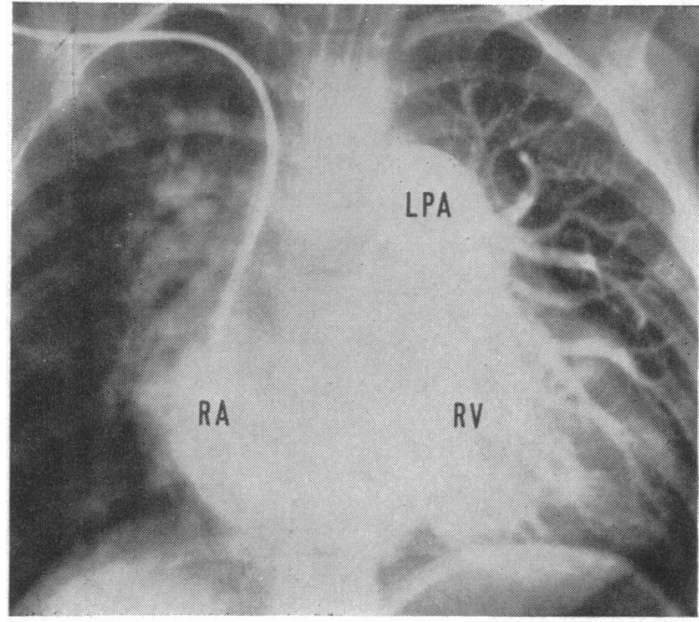

Fig. 14.-Anomalies of the pulmonary arteries. Right ventricular angiocardiogram of patient No. 4 with opacification of only the left pulmonary artery. RA = right atrium. LPA $=$ left pulmonary artery. $\mathrm{RV}=$ right ventricle

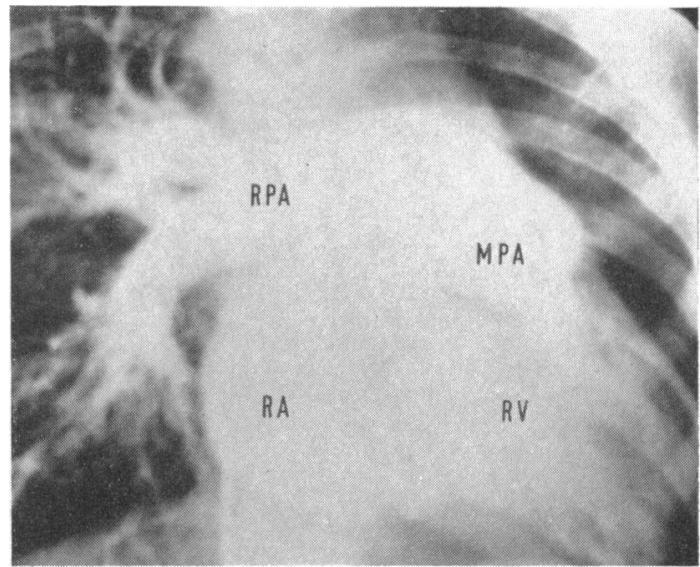

FIG. 13.-Anomalies of the pulmonary arteries. Angiocardiogram of patient No. 3 confirming absence of the left pulmonary artery. RA=right atrium. $\mathrm{RV}=$ right ventricle. $\mathrm{MPA}=$ main pulmonary artery. $\mathbf{R P A}=$ right pulmonary artery.

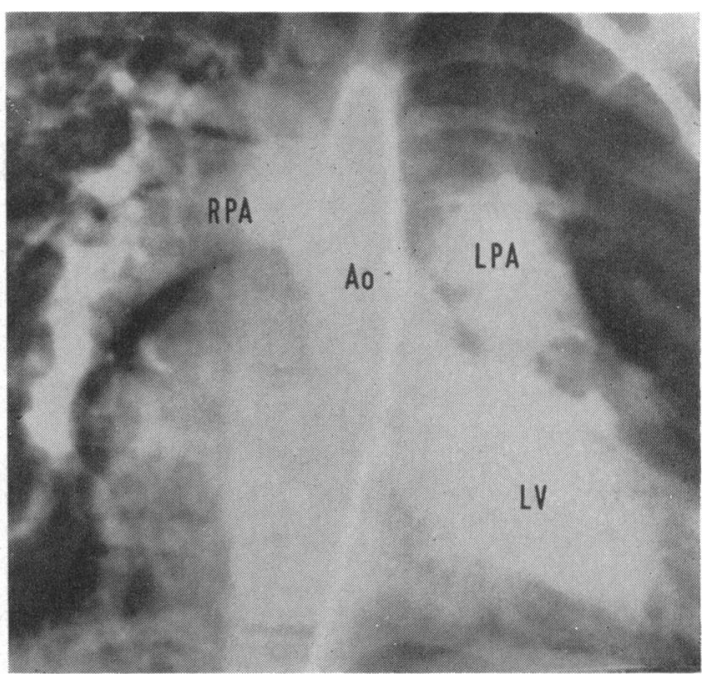

FIG. 15.-Anomalies of the pulmonary arteries. Left ventricular angiocardiogram of patient No. 4 showing the right pulmonary artery arising from the aorta. RPA = right pulmonary artery. LPA = left pulmonary artery. $\mathbf{L V}=$ left ventricle. 
and $\mathrm{X}$-ray findings provided some evidence, while selective angiocardiography provided the correct diagnosis. Any patient with ventricular septal defect with an unusual left cardiac border on X-ray or with a QR pattern in the right præcordial leads and an RS pattern in the left præcordial leads in the electrocardiogram should be suspected of having corrected transposition. This suspicion should become almost a certainty if complete heart block is present permanently or episodically, and there is mitral regurgitation.

The surgical treatment of lesions associated with corrected transposition can be extremely difficult owing to the technical problems produced by the ventricular inversion and the abnormal position of the coronary arteries. Many patients with corrected transposition are therefore not suitable for surgical correction, and this aspect will be reported later.

Angiocardiography is even more important for the diagnosis of double outlet right ventricle than for corrected transposition, for this condition is difficult, if not impossible, to diagnose clinically, especially in acyanotic patients. Even the selective angiocardiogram may be misleading, and very careful attention must be paid to the origin of the aorta if the diagnosis is not to be missed. Surgical correction has been successful in our experience in one patient with this condition, but the difficulties are obviously considerable and many patients will be considered unsuitable for operation.

Unilateral pulmonary stenosis does not usually influence a decision regarding operation in patients with ventricular septal defect. Following successful closure of the defect in one of our patients, the gradient and murmur associated with the branch stenosis disappeared with the relief of pulmonary hypertension.

Absence of the left pulmonary artery is not uncommon in patients with the tetralogy of Fallot or with Eisenmenger syndrome (Emanuel and Patinson, 1956). The association of ventricular septal defect with the right pulmonary artery arising from the aorta is very uncommon. Wagenvoort et al. (1961) have suggested that this anomaly is due to the presence of right patent ductus arteriosus, and failure of the right pulmonary artery to establish communication with the main pulmonary trunk. The right ductus will develop as a continuation of the right pulmonary artery, connecting it to the aorta. The diagnosis of such a lesion is of paramount importance, because we believe operation is contra-indicated.

We suggest, as a result of our experience, that unless the physical, radiological, and electrocardiographic examinations are in every way typical of an uncomplicated ventricular septal defect, selective angiocardiography should be performed. This can be done first from the right ventricle, and if doubt still exists, from the left ventricle, in order to exclude these serious and important associated anomalies that may influence the decision regarding surgical treatment. We would again stress that these anomalies are difficult to diagnose clinically and that they are by no means as rare as was previously thought.

\section{SUMMARY}

Twenty-four patients with anomalies of the great vessels in association with a ventricular septal defect have been presented. These patients have been divided into three groups: corrected transposition of the great vessels; double outlet right ventricle; and anomalies of the pulmonary arteries. The importance of selective angiocardiography in making the diagnosis of these defects and the associated clinical, radiological, and cardiographic signs is discussed. It is concluded that selective angiocardiography is important in patients with ventricular septal defect, especially if the physical signs or other clinical features are not absolutely typical. The presence of anomalies of the great vessels must influence the decision for or against surgical treatment of patients with ventricular septal defect.

We thank Dr. M. B. Bishop for pathological data and Messrs. W. P. Cleland and H. H. Bentall for operative details. 


\section{REFERENCES}

Ambrus, G. (1936). J. tech. Meth., 15, 103.

Anderson, R. C., Lillehei, C. W., and Lester, R. G. (1957). Pediatrics, 20, 626.

Arvidsson, H., Karnell, J., and Möller, T. (1955). Acta radiol. (Stockh.), 44, 209.

Beck, W., Schrire, V., Vogelpoel, L., Nellen, M., and Swanepoel, A. (1961). Brit. Heart J., $23,497$.

Cardell, B. S. (1956). Brit. Heart J., 18, 186.

Emanuel, R. W., and Pattinson, J. N. (1956). Brit. Heart J., 18, 289.

Harris, J. S., and Faber, S. (1939). Arch. Path., 28, 427.

Kjellberg, S. R., Mannheimer, E., Rudhe, U., and Jonsson, B. (1959). Diagnosis of Congenital Heart Disease. 2 nd. ed. Year Book Publishers, Chicago.

Lev, M. (1953). Autopsy Diagnosis of Congenitally Malformed Hearts. Charles C. Thomas., Springfield.

Madoff, I. M., Gaensler, E. A., and Strieder, J. (1952). New Engl. J. Med., 247, 149.

Nadas, A. S. (1961). Personal communication.

Neufeld, H. N., DuShane, J. W., Wood, E. H., Kirklin, J. W., and Edwards, J. E. (1961). Circulation, $23,399$.

Von Rokitansky, C. (1875). Die Defecte der Scheidewände der Herzens. Braumüller, Vienna.

Schiebler, G. L., Edwards, J. E., Burchell, H. B., DuShane, J. W., Ongley, P. A., and Wood, E. H. (1961). Pediatrics, 27, 851 .

Smith, W. G. (1958). Thorax, 13, 194.

Spitzer, A. (1923). Virchows Arch. path. Anat., 243, 81.

Wagenvoort, C. A., Neufeld, H. N., Birge, R. F., Caffrey, J. A., and Edwards, J. E. (1961). Circulation, $23,84$.

Witham, A. C. (1957). Amer. Heart J., 53, 928. 